\title{
Database Species-Area Relationships in Palaearctic Grasslands
}

\author{
Jürgen Dengler, Salza Todorova, Thomas Becker, Steffen Boch, Milan Chytrý, Martin \\ Diekmann, Christian Dolnik, Cecilia Dupré, Gian Pietro Giusso del Galdo, Riccardo \\ Guarino, Michael Jeschke, Kathrin Kiehl, Anna Kuzemko, Swantje Löbel, Zdenka \\ Otýpková, Hristo Pedashenko, Robert K. Peet, Eszter Ruprecht, Anna Szabó, loannis \\ Tsiripidis \& Kiril Vassilev
}

\begin{abstract}
The Database Species-Area Relationships in Palaearctic Grasslands (GIVD ID EU-00-003) is an initiative of the European Dry Grassland Group (EDGG) and primarily functions as repository for all data sampled during the EDGG Research Expeditions. During these expeditions two types of highly standardised sampling of dry grassland vegetation in the Palaearctic realm are carried out: (i) nested-plot sampling on squares of $0.0001,0.001,0.01,0.1,1,10$, and $100 \mathrm{~m}^{2}$; (ii) additional normal relevés of 10 - $\mathrm{m}^{2}$ plots. For all plot sizes, the terricolous vascular plants, bryophytes, and lichens are recorded that are superficially present (shoot presence). Additionally, for all $10-\mathrm{m}^{2}$ plots species cover is estimated directly in percent and a wide range of topographic, soil, and land use parameters is determined. Five such expeditions have been carried out so far (2009: Transylvania, Romania; 2010: Central Podolia, Ukraine; 2011: NW Bulgaria; 2012a: Sicily, Italy; 2012b: N Greece). Additionally, the database contains similar nested-plot data from published and unpublished sources covering dry grasslands in Czech Republic, Estonia, Germany, the Netherlands, Russia, Sweden, Switzerland, and the United Kingdom. The vegetation classes Festuco-Brometea and Koelerio-Corynephoretea prevail, but there are also some data from Mediterranean grasslands. Presently, the database contains data from 402 nested-plot series plus 325 separate 10$\mathrm{m}^{2}$ plots. Data from future EDGG Expeditions will be added and we are open to add other nested-plot data from any type of grassland in the Palaearctic. This huge collection of nested-plot data is very valuable for the study of species-area relationships (SARs) in grasslands and how their function types and parameters (e.g. the z-values of the power-law SARs) depend on grassland type, region, and taxon considered. The 10- $\mathrm{m}^{2}$ plots from the EDGG Expeditions (from inside and outside the nested plots) are an important contribution to consistent large-scale classifications as they were sampled by using a uniform plot size, recording also non-vascular plants, and consistently determining a set of plot-based plot-based environmental variables. The dataset will be available to the scientific public based on individual arrangements.
\end{abstract}

Keywords: biodiversity; bryophyte; dry grassland; European Dry Grassland Group (EDGG); Festuco-Brometea; KoelerioCorynephoretea; lichen; Mediterranean grassland; scale dependence; soil data.

\section{Database Species-Area Relationships in Palaearctic Grasslands}

Scope: The database collects the data resulting from the sampling of species-area relationships (SARs) in grassland communities in the Palaearctic. The core features of the database are the complete data from the EDGG Research Expeditions, but similar data from other studies are also included. Main features of the majority of relevés are: (i) they are part of nested-plot series (typically 0.0001-100 m²), (ii) bryophytes and lichens are treated comprehensively; (iii) detailed soil and other environmental data.

Status: emerging Period: 1949-2012

Database manager(s): Jürgen Dengler (juergen.dengler@uni-hamburg.de); Salza Todorova (salza.todorova@gmail.com)

Owner: European Dry Grassland Group (EDGG)

Web address: $[\mathrm{NA}]$

Availability: according to a specific agreement

Online upload: no

Online search: no

Database format(s): Excel

Export format(s): Excel

Publication: Dengler, J. (2009): A flexible, multi-scale approach for standardised recording of plant species richness patterns. - Ecological Indicators 9: 1169-1178.

Plot type(s): normal plots; nested plots

Non-overlapping plots: 727

Total plot observations: 7,202

Countries: BG: 9.9\%; CH: 3.0\%; CZ: 12.3\%; DE: 7.4\%; EE: 2.2\%; GB: 0.4\%; GR: 2.3\%; IT: 6.3\%; NL: 0.4\%; RO: 8.5\%; RU: 7.9\%; SE: 9.2\%; UA: $30.0 \%$

Forest: $0 \%$ - Non-forest: aquatic: $0 \%$; semi-aquatic: $0 \%$; arctic-alpine: $0 \%$; natural: $0 \%$; semi-natural: $100 \%$; anthropogenic: $0 \%$ Guilds: all vascular plants: $100 \%$; bryophytes (terricolous or aquatic): $81 \%$; lichens (terricolous or aquatic): $81 \%$; algae (terricolous or aquatic): $81 \%$; non-terricolous taxa (epiphytic, saxicolous, lignicolous): $16 \%$ 
Environmental data: altitude: $100 \%$; slope aspect: $69 \%$; slope inclination: $69 \%$; microrelief: $53 \%$; soil depth: $40 \%$; surface cover other than plants (open soil, litter, bare rock etc.): $61 \%$; soil pH: $47 \%$; other soil attributes: $48 \%$; land use categories: $72 \%$

Performance measure(s): cover: $100 \%$

Geographic localisation: GPS coordinates (precision $25 \mathrm{~m}$ or less): $80 \%$; point coordinates less precise than GPS, up to $1 \mathrm{~km}$ : $20 \%$

Sampling periods: 1940-1949: 0.4\%; 1990-1999: 6.2\%; 2000-2009: 44.8\%; 2010-2019: 48.6\%

Information as of 2012-07-25; further details and future updates available from http://www.givd.info/ID/EU-00-003

Jürgen Dengler* (juergen.dengler@uni-hamburg.de)

Biodiversity, Evolution and Ecology of Plants (BEE), Biocentre Klein Flottbek and Botanical Garden, University of Hamburg,

Ohnhorststr. 18, 22609 Hamburg, GERMANY

Salza Todorova (salza.todorova@gmail.com), Milan Chytrý (chytry@ sci.muni.cz ), Zdenka Otýpková (zdenkao@sci.muni.cz) Department of Botany and Zoology, Masaryk University, Kotlarska 2, 61137 Brno, CZECH REPUBLIC

Thomas Becker (beckerth@uni-trier.de ), Michael Jeschke (jeschke@uni-trier.de)

Department of Geobotany, Faculty of Geography and Geosciences, University of Trier, Behringstr. 21, 54296 Trier, GERMANY

Steffen Boch (steffen.boch@ips.unibe.ch )

Institute of Plant Sciences and Botanical Garden, University of Bern, Altenbergrain 21, 3013 Bern, SWITZERLAND

Martin Diekmann (mdiekman@uni-bremen.de), Cecilia Dupré (dupre@uni-bremen.de)

Vegetation Ecology and Conservation Biology, Institute of Ecology, University of Bremen, Leobener Str. 11, 28359 Bremen, GERMANY

Christian Dolnik (cdolnik@ecology.uni-kiel.de )

Institute for Natural Resource Conservation, Ecology Centre Kiel, Christian Albrechts University Kiel, Olshausenstr. 40, 24098 Kiel, GERMANY

Gian Pietro Giusso del Galdo (g.giusso@unict.it)

Dipartimento di Scienze Biologiche, Geologiche e Ambientali, University of Catania, via A. Longo, 19, 95125 Catania, ITALY

Riccardo Guarino (guarinotro@ hotmail.com )

Dipartimento di Biologia Ambientale e Biodiversità, University of Palermo, via Archirafi, 38, 90123 Palermo, ITALY

Kathrin Kiehl (k.kiehl@hs-osnabrueck.de )

Vegetation Ecology and Botany, University of Applied Sciences Osnabrück, Oldenburger Landstr. 24, 49090 Osnabrück, GERMANY

Anna Kuzemko (anya_meadow@mail.ru)

National Dendrological Park 'Sofievka', National Academy of Sciences of Ukraine, 12a Kyivska str., 20300 Uman', UKRAINE

Swantje Löbel (swantje.lobel@ebc.uu.se )

Department of Plant Ecology, Evolutionary Biology Centre, Uppsala University, Norbyvägen 18D, 75236 Uppsala, SWEDEN

Hristo Pedashenko (hristo_pedashenko@yahoo.com), Kiril Vassilev (kiril5914@abv.bg )

Department Plant and Fungi Diversity and Resources, Institute of Biodiversity and Ecosystem Research, Bulgarian Academy of Sciences, 23 Acad. G. Bonchev Str., 1113 Sofia, BULGARIA

Robert K. Peet (peet@unc.edu)

Department of Biology, CB\#3280, University of North Carolina, 27599-3280 Chapel Hill, NC, UNITED STATES

Eszter Ruprecht (eszter.ruprecht@ubbcluj.ro ), Anna Szabó (annuc19@gmail.com)

Faculty of Biology and Geology, Babeş-Bolyai University Cluj-Napoca, Republicii Street 42, 400015 Cluj-Napoca, ROMANIA

Ioannis Tsiripidis (tsiripid@bio.auth.gr)

School of Biology, Aristotle University of Thessaloniki, GR-54124 Thessaloniki, GREECE

*Corresponding author 